\title{
Untreated Childhood Anaplastic Oligodendroglioma
}

National Cancer Institute

\section{Source}

National Cancer Institute. Untreated Childhood Anaplastic Oligodendroglioma. NCI

Thesaurus. Code C115922.

A finding of anaplastic oligodendrog lioma in childhood that has not been treated. 